\title{
Effects of oestradiol on LH, FSH and prolactin in ovariectomized ewes*
}

\author{
T. G. Rozell and D. H. Keisler \\ Animal Sciences Department, University of Missouri, Columbia, Missouri 65211, USA
}

\begin{abstract}
Summary. This study was conducted to test the hypothesis that the rate (dose/time) at which oestradiol-17 $\beta$ (oestradiol) is presented to the hypothalamo-pituitary axis influences secretion of LH, FSH and prolactin. A computer-controlled infusion system was used to produce linearly increasing serum concentrations of oestradiol in ovariectomized ewes over a period of $60 \mathrm{~h}$. Serum samples were collected from ewes every $2 \mathrm{~h}$ from $8 \mathrm{~h}$ before to $92 \mathrm{~h}$ after start of infusion, and assayed for oestradiol, LH, FSH and prolactin. Rates of oestradiol increase were categorized into high $(0.61-1.78 \mathrm{pg} / \mathrm{h})$, medium $(0.13-0.60 \mathrm{pg} / \mathrm{h})$ and low $(0.01-0.12 \mathrm{pg} / \mathrm{h})$. Ewes receiving high rates of oestradiol $(\mathrm{N}=11)$ responded with a surge of $\mathrm{LH} 12.7 \pm 2.0 \mathrm{~h}$ after oestradiol began to increase, whereas ewes receiving medium $(\mathrm{N}=15)$ and low $(\mathrm{N}=11)$ rates of oestradiol responded with a surge of $\mathrm{LH}$ at $19.4 \pm 1.7$ and $30.9 \pm 2.0 \mathrm{~h}$, respectively. None of the surges of LH was accompanied by a surge of FSH. Serum concentrations of FSH decreased and prolactin increased in ewes receiving high and medium rates of oestradiol, when compared to saline-infused ewes $(N=8 ; P<0.05)$. We conclude that rate of increase in serum concentrations of oestradiol controls the time of the surge of LH and secretion of prolactin and FSH in ovariectomized ewes. We also suggest that the mechanism by which oestradiol induces a surge of LH may be different from the mechanism by which oestradiol induces a surge of FSH.
\end{abstract}

Keywords: oestradiol; LH; FSH; prolactin; ovariectomized ewes

\section{Introduction}

Serum concentrations of oestradiol increase before preovulatory surges of LH and FSH (Baird et al., 1981; Goodman et al., 1981; Karsch et al., 1984; Keisler et al., 1985). Furthermore, oestradiol is reported to stimulate secretion of prolactin in ewes (Baird et al., 1981; Elsasser et al., 1983). To understand how the preovulatory increase in serum concentrations of oestradiol regulates secretion of gonadotrophins in ewes, investigators have utilized ovariectomized ewes treated with injections of oestradiol (Goding et al., 1969; Elsasser et al., 1983; Haresign \& Friman, 1983; Nett et al., 1984; Clarke et al., 1988), constant infusions of oestradiol (Goding et al., 1969; Emons et al., 1984) or implants of oestradiol (Karsch et al., 1980; Foster, 1984; Keisler et al., 1985). Treatment of ewes with oestradiol by these methods, however, produces patterns of serum concentrations of oestradiol which are non-linear, and therefore dissimilar to those which occur before ovulation in the ewe. By fitting regression equations to the increase in serum concentrations of oestradiol which occur during the follicular phase of cyclic ewes (Karsch et al., 1984) and in lambs induced to ovulate by repeated injections of LH (Keisler et al., 1985), we determined that preovulatory serum concentrations of oestradiol increase in a linear fashion at a rate of approximately $0.08 \mathrm{pg} / \mathrm{h}$.

*Reprint requests to Dr D. H. Keisler, 160 Animal Science Research Center, University of Missouri, Columbia, MO 65211, USA. 
Our objectives in the present study were to produce different rates of linearly increasing serum concentrations of oestradiol in ovariectomized ewes to: (1) determine whether the gonadotrophin surge mechanism is activated by a threshold dose of oestradiol, duration of exposure to oestradiol, or the interaction of dose and duration (i.e. rate) of oestradiol; and (2) examine the pattern of gonadotrophin secretion in response to different rates of increasing serum concentrations of oestradiol. We tested the hypothesis that the rate (dose/time) at which oestradiol is presented to the hypothalamo-pituitary axis influences the time and magnitude of the surges of LH and FSH, and the secretion of prolactin.

\section{Materials and Methods}

Twelve mature, chronically ( $\geq 3$ months) ovariectomized and hysterectomized ewes of mixed breeding were selected for study. Ewes were randomly assigned before each trial to receive either an intravenous infusion of saline $(0.9 \%$ $(\mathrm{w} / \mathrm{v}) \mathrm{NaCl}$ in sterile distilled water; $\mathrm{pH} 7.0)$ or a saline solution containing oestradiol. Five trials were conducted between June and December 1988, with 3 or more weeks between each trial. Two days before each trial, ewes were relocated from pasture to indoor $2 \mathrm{~m} \times 2 \mathrm{~m}$ pens and housed for 7 days. While indoors, ewes were fed $4 \mathrm{~kg}$ of a mixed grain ration 3 times per day and fresh water was available at all times. Ewes were tied to stanchions and fitted with indwelling jugular cannulae $24 \mathrm{~h}$ before infusion. Cannulae were placed caudally in each jugular vein, one for infusion and the other for blood sampling. During each trial, ewes were infused with saline or oestradiol delivered in $100 \mu \mathrm{l}$ drops by a computer-controlled, gravity-flow infusion system programmed to produce linearly increasing serum concentrations of oestradiol in each ewe over a period of $60 \mathrm{~h}$. This was accomplished by increasing mass (volume) of oestradiol delivered over time.

Solutions of oestradiol to be infused were made by diluting a concentrated solution of oestradiol $(150 \mu \mathrm{g} / \mathrm{ml} \mathrm{in}$ ethanol) in 3 litres of saline. Solutions of oestradiol (Sigma Chemical Co., St Louis, MO, USA) varied in concentration from a maximum of $720 \mathrm{ng} / \mathrm{ml}$ to a minimum of $10 \mathrm{ng} / \mathrm{ml}$. A total of 2 litres of saline or oestradiol in saline were delivered to each animal during the 60 -h infusion period.

Blood samples $(10 \mathrm{ml})$ were collected at 2 -h intervals beginning $8 \mathrm{~h}$ before infusion and ending $32 \mathrm{~h}$ after infusion. Samples were allowed to clot at room temperature for $4 \mathrm{~h}$ before centrifugation. Serum was decanted and stored at $-20^{\circ} \mathrm{C}$ until assayed. Serum concentrations of oestradiol, $\mathrm{LH}, \mathrm{FSH}$ and prolactin were determined by radioimmunoassays.

Assays. Serum concentrations of oestradiol were determined in duplicate $500 \mu l$ samples. Sample and standard curve tubes were twice extracted with anhydrous diethyl ether $(4.0 \mathrm{ml} / \mathrm{tube})$. Efficiency of extraction of oestradiol from samples averaged $92 \%$. A standard solution of oestradiol in methanol was pipetted in triplicate to create a standard curve with the following points: $0 \cdot 25,0 \cdot 50,1 \cdot 0,2 \cdot 5,5 \cdot 0,10 \cdot 0$ and $20 \cdot 0 \mathrm{pg} /$ tube. The methanol containing the oestradiol standard was evaporated and $100 \mu \mathrm{l}$ of a $1 \%$ BSA solution in PBS were then added to each standard curve and sample tube. Oestradiol antiserum $(100 \mu \mathrm{l}$ of a 1:85 500 dilution of antiserum; Butcher $e t$ al., 1974) was added to each tube except total and non-specific binding tubes. Tubes were incubated at $37^{\circ} \mathrm{C}$ for $5 \mathrm{~min}$, then at $4^{\circ} \mathrm{C}$ for $1 \mathrm{~h}$, after which $100 \mu \mathrm{i}$ 3-iodo-oestradiol-17ß (4.0 pg/tube; ICN Biomedicals, Inc., Carson, CA, USA) were added to each tube. Tubes were then incubated for an additional $15 \mathrm{~h}$ at $4^{\circ} \mathrm{C}$, and then $800 \mu \mathrm{l}$ of a charcoal-dextran suspension in double-distilled water were added to each tube except total tubes. Tubes were vortexed and incubated for $10 \mathrm{~min}$ at $4^{\circ} \mathrm{C}$, then centrifuged at $4^{\circ} \mathrm{C}$ and $3000 \mathrm{~g}$ for $10 \mathrm{~min}$. The supernatant was decanted into a separate set of tubes and each was counted for $1 \mathrm{~min}$ in a gamma counter. The intra- and inter-assay coefficients of variation for the oestradiol assay were $9.71 \%(\mathrm{~N}=8)$ and $12.8 \%(\mathrm{~N}=8)$, respectively. Minimum detectable concentrations of oestradiol were $0.37 \mathrm{pg} /$ tube.

Serum concentrations of $\mathrm{LH}$ were assayed in duplicate $100 \mu \mathrm{l}$ samples by the methods described by Fogwell et al. (1977), utilizing RAoLH TEA $\$ 35$ ovine LH antiserum (Adams et al., 1975). The inter- and intra-assay coefficients of variation were $3 \cdot 2 \%(\mathrm{~N}=5)$ and $12.6 \%(\mathrm{~N}=9)$, respectively, with a minimum detectable concentration of $50 \mathrm{pg} /$ tube.

Serum concentrations of FSH were determined in duplicate $25-\mu \mathrm{l}$ samples as described by Keisler et al. (1983) utilizing materials and methods provided by NIDDḰ. Inter- and intra-assay coefficients of variation were $12.0 \%$ $(\mathrm{N}=9)$ and $19.0 \%(\mathrm{~N}=9)$, respectively, and minimum detectable concentrations of FSH were $60 \mathrm{pg} / \mathrm{tube}$.

Serum concentrations of prolactin were determined in duplicate 10- $\mu 1$ samples as described by Keisler et al. (1983), utilizing materials and methods provided by NIDDKD. Inter- and intra-assay coefficients of variation were $15 \cdot 2 \%$ $(\mathrm{N}=9)$ and $17.4 \%(\mathrm{~N}=9)$, respectively, and minimum detectable concentrations of prolactin were $80 \mathrm{pg} /$ tube.

Statistical analysis. The rate at which serum concentrations of oestradiol increased in each ewe was determined by fitting a regression line to assayed serum concentrations of oestradiol determined for each ewe during the 60-h infusion period. For purposes of analysis, the rates of oestradiol increase were categorized into 3 groups: $0.01-$ $0.12 \mathrm{pg} / \mathrm{h}, 0.13-0.60 \mathrm{pg} / \mathrm{h}$ or $0.61-1.78 \mathrm{pg} / \mathrm{h}$. Differences in time of onset and magnitude of the surge of $\mathrm{LH}$ among the 3 groups were tested using the General Linear Models (GLM) procedure of the Statistical Analysis System (SAS, 1985) and, when appropriate, by Duncan's New Multiple Range Test (Steel \& Torrie, 1980). The relationship between 
dose and duration of oestradiol exposure at which each ewe responded with a surge of LH was determined by fitting a non-linear, non-polynomial regression line (NLIN procedure; SAS, 1985) to values obtained from each ewe. Differences in the profile of serum concentrations of FSH and prolactin among the 3 groups of rates were determined by analysis of variance using a split-plot design, with time and the interaction of time and rate of oestradiol increase in the subplot (Gill \& Hafs, 1971). The correlation between the pattern of serum concentrations of oestradiol and the pattern of FSH and prolactin in each ewe was determined by using the regression (REGRESSION) procedure of SAS (1985).

\section{Results}

\section{Oestradiol infusion}

Linearly increasing serum concentrations of oestradiol were established and maintained over a 60-h infusion period in 37 of 52 attempts. Samples collected during the 15 attempts in which linear infusions failed to be maintained for $60 \mathrm{~h}$ were not assayed for gonadotrophins. The rate at which oestradiol increased during successful oestradiol infusions ranged from 0.01 to $1.78 \mathrm{pg} / \mathrm{h}$ and all patterns of serum concentrations of oestradiol were different from those in saline-treated ewes $(\mathrm{N}=8 ; P<0.05)$. No differences were found in serum concentrations of oestradiol as the result of infusions of oestradiol at different times during the year (June to December).

\section{Effects on the surge of LH}

Ewes which received oestradiol at high rates $(\mathrm{N}=11)$ responded with a surge of $\mathrm{LH}$ $12 \cdot 7 \pm 2 \cdot 0 \mathrm{~h}$ after oestradiol began to increase (Fig. 1). In contrast, when serum concentrations of oestradiol increased at medium $(\mathrm{N}=15)$ and low $(\mathrm{N}=11)$ rates, the interval to the onset of the surge of $\mathrm{LH}$ increased to $19.5 \pm 1.7$ and $30.9 \pm 2.0 \mathrm{~h}$, respectively (Fig. 1). The dose and duration of oestradiol at which each of the 37 ewes responded with a surge of $\mathrm{LH}$ are illustrated in Fig. 2. A non-linear, non-polynomial regression line represented by the equation: dose increase in oestradiol in $\mathrm{pg} / \mathrm{ml}=29 \cdot 45[1 / \text { (hour of infusion at which the surge of } \mathbf{L H} \text { occurred }-7)^{0.506}$ ] (solid line; Fig. 2) illustrates the relationship between dose and duration of oestradiol at which each ewe responded with a surge of $\mathrm{LH}$. Magnitude of the surge of $\mathrm{LH}$ was $22.6 \pm 4 \cdot 1,33 \cdot 1 \pm 3 \cdot 5$ and $33 \cdot 5 \pm 4 \cdot 1 \mathrm{ng} / \mathrm{ml}$ for ewes receiving high, medium and low rates of increasing concentrations of oestradiol, respectively, and were not different $(P>0.05)$. Ewes receiving saline $(\mathrm{N}=8)$ did not respond with a surge of $\mathrm{LH}$. Patterns of serum concentrations of $\mathrm{LH}$ produced during the negative feedback effects of oestradiol, and initial serum concentrations of $\mathrm{LH}$ did not differ $(P>0.05)$ among the 5 trials.

\section{Effects on serum concentrations of FSH}

The patterns of serum concentrations of FSH and oestradiol in each ewe were negatively correlated $(\mathrm{R}=-0.58 ; P<0.05)$. Serum concentrations of FSH decreased over time $(P<0.05 ;$ Fig. 3$)$ in ewes receiving high and medium, but not low, rates of oestradiol, compared to saline-infused ewes. Serum concentrations of FSH were not different $(P>0.05)$ in ewes receiving high and medium rates of oestradiol. The time at which concentrations of FSH were maximally decreased was not different $(P>0.05)$ between ewes receiving high and medium rates of oestradiol. Initial serum concentrations of FSH throughout the infusion period did not differ $(P>0.05)$ among the 5 trials.

\section{Effects on serum concentrations of prolactin}

The patterns of serum concentrations of prolactin and oestradiol were positively correlated ( $\mathrm{R}=0.77 ; P<0.05 ;$ Fig. 4$)$. Serum concentrations of prolactin increased $(P<0.05)$ in ewes 


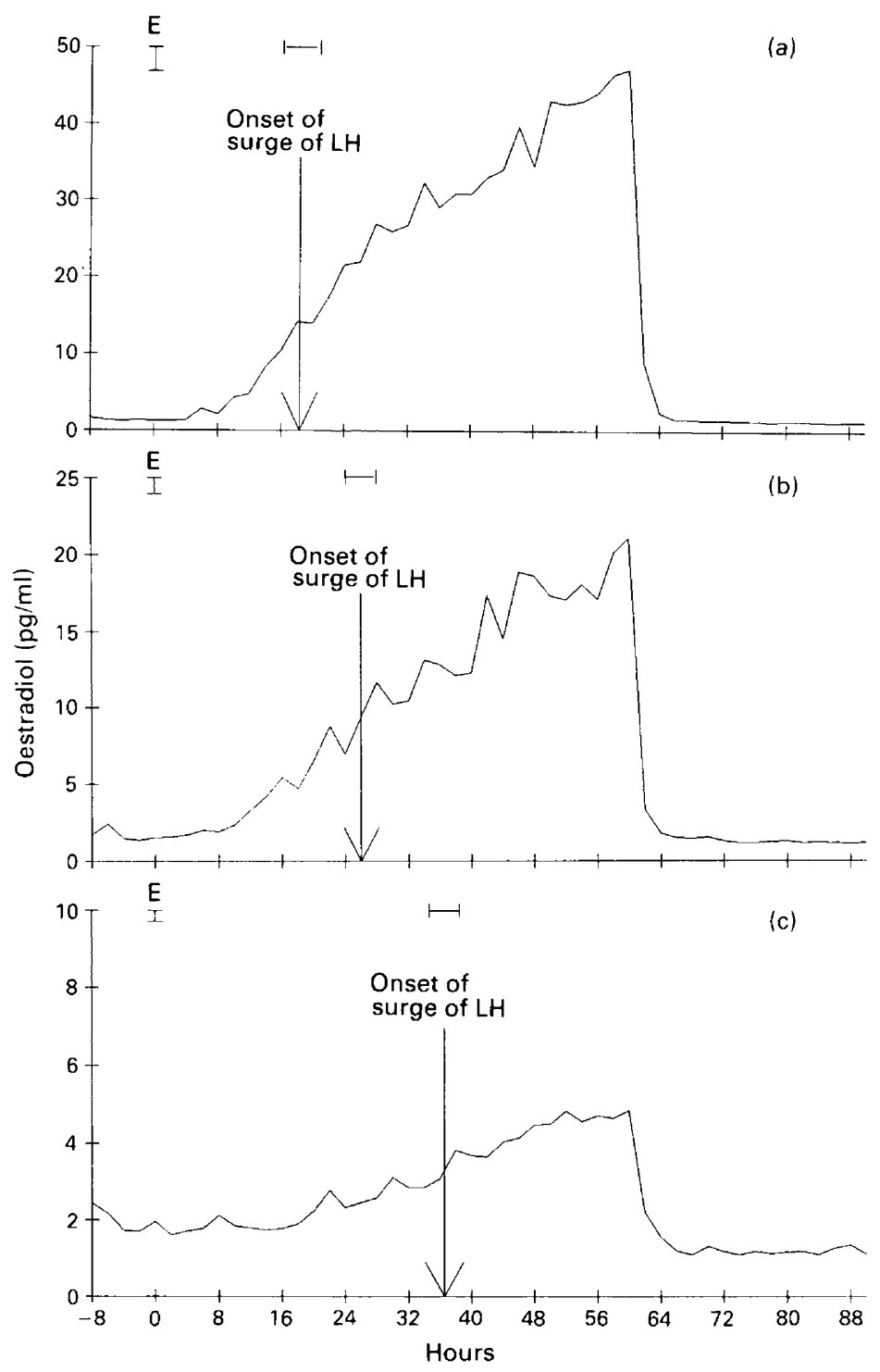

Fig. 1. Relationship between serum concentrations of oestradiol and onset of the surge of LH in ewes receiving (a) high $(\mathrm{N}=11)$, (b) medium $(\mathrm{N}=15)$ and (c) low $(\mathrm{N}=11)$ rates of increasing concentrations of oestradiol. Hour 0 represents the point at which infusions of oestradiol were initiated. Standard error bars represent least squares means standard error in each of the three treatment groups, for oestradiol (E; vertical bars) and for time of the surge of LH (horizontal bars).

receiving high and medium rates of oestradiol, but concentrations of prolactin in ewes which received low rates of oestradiol were not different $(P>0.05)$ from those in saline-infused ewes. Maximum serum concentrations of prolactin and the time at which maximum serum concentrations of prolactin was obtained did not differ $(P>0.05)$ among ewes receiving high and medium rates of oestradiol. Initial serum concentrations of prolactin did not differ $(P>0.05)$ among the 5 trials. 


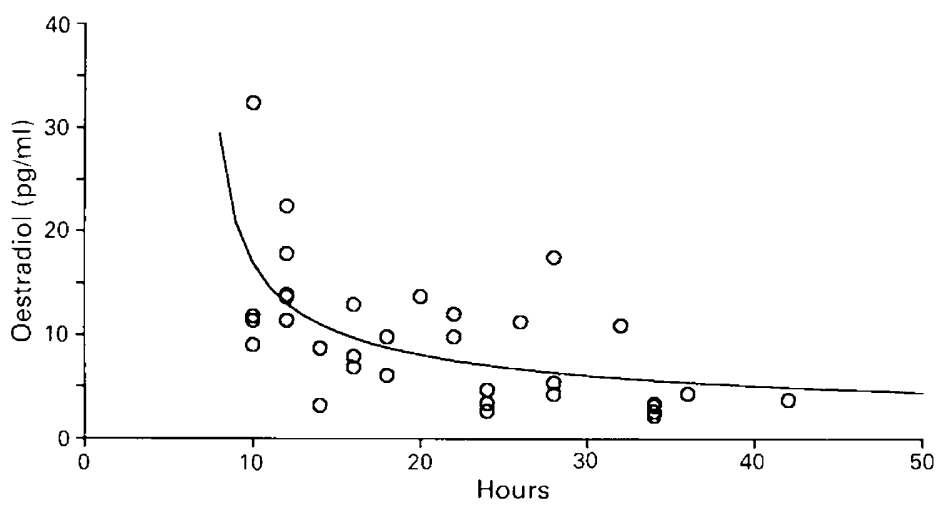

Fig. 2. Relationship between the dose and duration of exposure to increasing concentrations of oestradiol at which each ewe responded with a surge of LH (open circles) as represented by the non-linear, non-polynomial regression line described by the equation: dose increase in oestradiol in $\mathrm{pg} / \mathrm{ml}=29 \cdot 45\left[1 /(\text { hour of infusion at which the surge of LH occurred }-7)^{0.506}\right]$.

\section{Discussion}

The relationship between dose of oestradiol and duration of oestradiol exposure (the interaction of which is rate) at which a surge of LH occurred in ovariectomized ewes was studied. Ewes receiving high rates of oestradiol had a surge of $\mathrm{LH}$ an average of $12 \pm 3.0 \mathrm{~h}$ after oestradiol began to increase, and this 12-h period was not dependent on the dose of oestradiol at the time of the surge of LH. Other investigators have found an interval of about $12 \mathrm{~h}$ between oestradiol treatment and the surge of LH in response to injection (Goding et al., 1969; Elsasser et al., 1983; Haresign \& Friman, 1983; Nett et al., 1984), constant infusion (Goding et al., 1969; Emons et al., 1984) or implantation of oestradiol (Foster, 1984; Keisler et al., 1985). This minimum amount of time is most probably required for protein synthetic events which are stimulated by oestradiol, such as synthesis of GnRH (Zoeller \& Young, 1988; Ronnekleiv et al., 1989) and LH (Landefeld \& Kepa, 1984; Leung et al., 1988; Marshall et al., 1989), and synthesis and up-regulation of GnRH receptors in the pituitary (Moss et al., 1981; Crowder et al., 1982; Nett et al., 1984; Clarke et al., 1988; Gregg \& Nett, 1989). Nett et al. (1984), however, reported that a surge of LH occurred after $4 \mathrm{~h}$ if oestradiol was injected in the presence of a constant infusion of GnRH. Therefore, much of the 12-h period observed in the present and other studies may be necessary to increase synthesis and/or secretion of GnRH. Regardless of the mechanisms involved, a delay of $12 \mathrm{~h}$ after oestradiol exposure may enable the surge of $\mathrm{LH}$ to be of sufficient amplitude and duration to cause ovulation and formation of the corpus luteum.

Ewes given low rates of oestradiol in the present study responded with a surge of $\mathrm{LH}$ which occurred at a lower dose, but required a longer duration of oestradiol exposure, than did ewes receiving high rates of oestradiol. The dose of oestradiol at which the surge occurred in ewes receiving low rates of oestradiol was $3.25 \pm 0.2 \mathrm{pg}$, which may be the minimum increase in serum concentrations of oestradiol necessary to stimulate a surge of $\mathrm{LH}$. A minimum dose is perhaps necessary to ensure that sufficient oestradiol receptors are bound to initiate a response.

We suggest that our findings support the hypothesis that the minimum dose and minimum duration of oestradiol exposure necessary to induce a surge of LH are influenced primarily by the rate at which oestradiol is presented to the hypothalamic LH surge centre. Although the mechanism by which the rate of oestradiol increase interacts with the surge centre is unknown, its functional significance may be to provide the ewe with a way of compensating for rates of oestradiol increase which are above or below normal. 


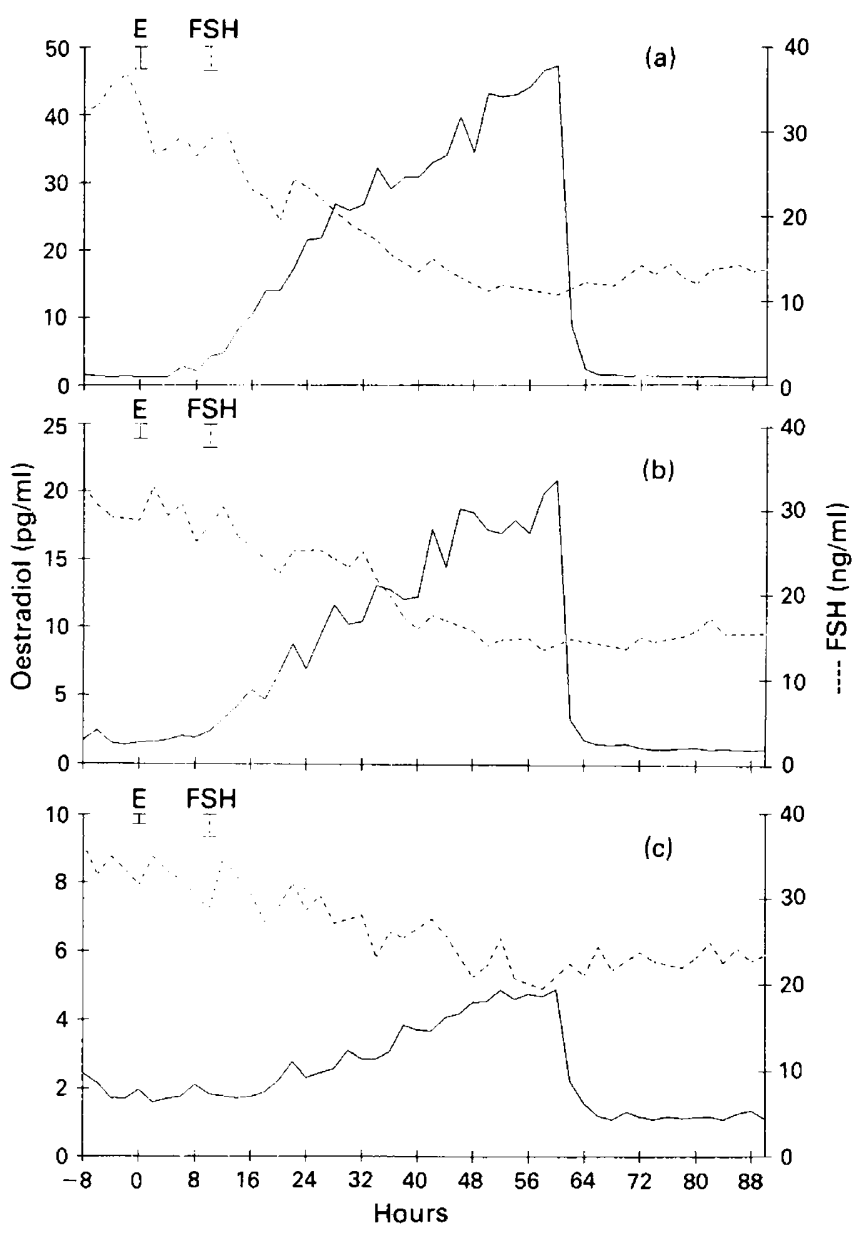

Fig. 3. Response of FSH to (a) high, (b) medium and (c) low rates of increasing serum concentrations of oestradiol. Hour 0 represents the point at which infusions of oestradiol were initiated. Standard error bars represent least squares means standard error in each of the 3 groups, for oestradiol (E; solid) and for FSH (broken).

In contrast to the positive feedback effects, negative feedback actions of oestradiol on secretion of $\mathrm{LH}$ were not responsive to the rate of oestradiol increase. The negative feedback actions of oestradiol are therefore not merely the inverse of its stimulatory actions on mechanisms which initiate a surge of LH. A possible explanation for inhibitory effects of oestradiol on secretion of $\mathrm{LH}$ is that oestradiol may directly activate a sequence of events in the pituitary which include decreases in: (1) adenylate cyclase activity (Harden et al., 1980), (2) releasable pituitary stores of LH (Koninckx et al., 1976), (3) number of cells responsive to GnRH (Lloyd \& Childs, 1988), and/or (4) plasma membrane potentials. Alternatively, the inhibitory effects of oestradiol may be mediated by an oestradiol-induced release of hypothalamic proteins which may inhibit the secretion of $\mathrm{LH}$ (Hwan \& Freeman, 1987).

In cyclic ewes, surges of FSH occur concomitantly with surges of LH (Baird et al., 1981). In the present study, however, no surges of FSH occurred in the 37 successful infusions of oestradiol and secretion of FSH was inhibited in a dose-dependent manner by infusion of oestradiol at different rates. Our results provide evidence that oestradiol regulates the secretion of FSH differently from that of $\mathrm{LH}$, and that the preovulatory surge of FSH may be mediated by ovarian factors other than 


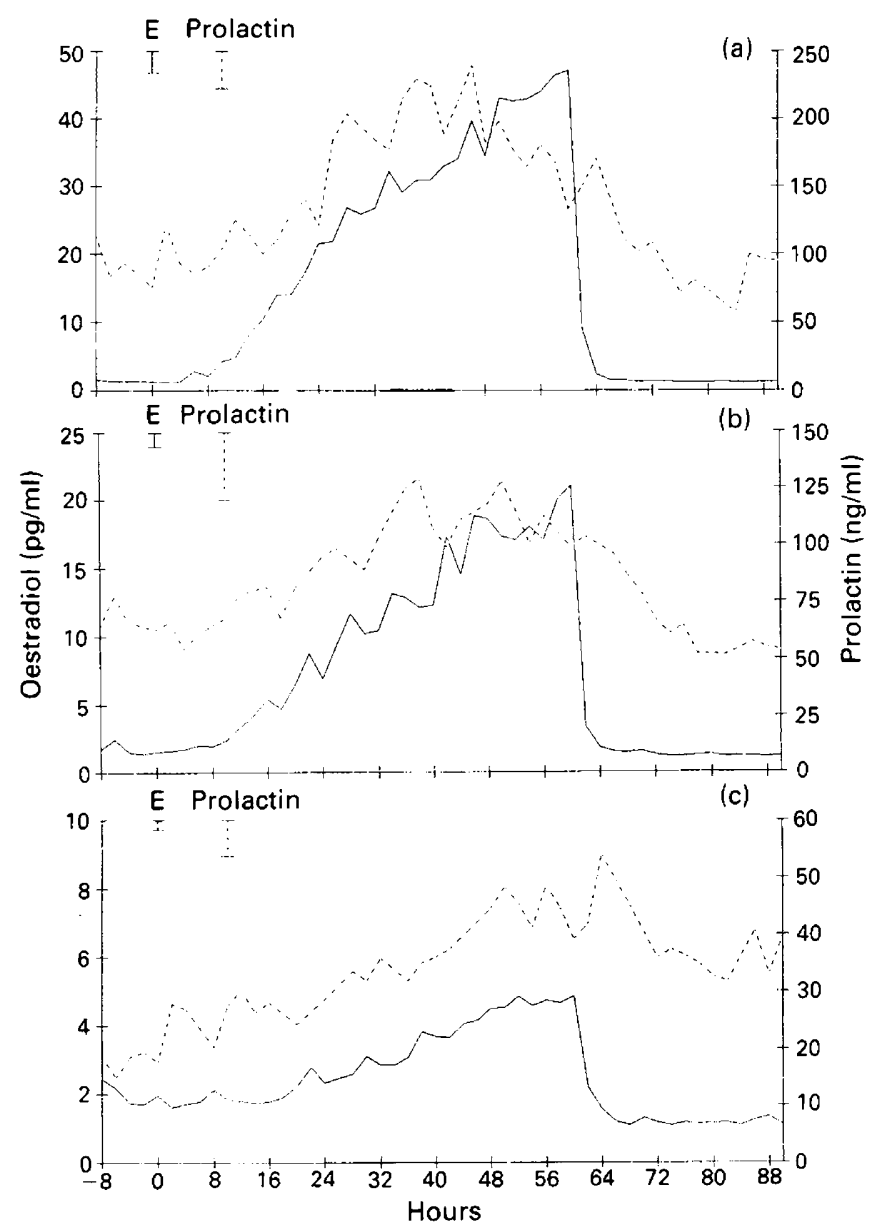

Fig. 4. Response of prolactin to (a) high, (b) medium and (c) low rates of linearly increasing serum concentrations of oestradiol. Hour 0 represents the point at which infusions of oestradiol were initiated. Standard error bars represent least squares means standard error in each of the 3 groups for oestradiol (E; solid) and for prolactin (broken).

oestradiol. Other investigators have found suppression of FSH concurrent with stimulation of $\mathrm{LH}$ in long-term ovariectomized ewes given an implant (Clarke et al., 1989) or injection (Elsasser et al., 1983) of oestradiol. Oestradiol was also found to cause a dose-dependent suppression of FSH in ewes both in vitro and in vivo (Henderson et al., 1989). However, injection or implantation of oestradiol results in patterns of serum concentrations of oestradiol in ewes which are different from those found in intact ewes before ovulation, and therefore patterns of oestradiol caused by injection or implantation in these studies may have been insufficient to cause the surge of FSH. Serum concentrations of FSH were also observed to decrease as oestradiol increased in cyclic ewes (Baird et al., 1981). These investigators, however, observed that a surge of FSH occurred after oestradiol concentrations had decreased following ovulation. Our findings provide evidence that the preovulatory increase and subsequent decline in oestradiol may not be responsible for the surge of FSH.

The mechanism by which oestradiol inhibits secretion of FSH is unknown, but may be different from the mechanism by which oestradiol inhibits secretion of LH. Secretion of FSH was inhibited in a dose-dependent manner, while inhibition of LH was not dose-dependent in the present study. 
Shupnik et al. (1988) reported that oestradiol regulates synthesis of FSH differently from that of LH. This may account in part for continued inhibition of FSH by oestradiol, even during a surge of LH which is presumed to be caused by increasing concentrations of GnRH (Clarke \& Cummins, 1982; Levine \& Duffy, 1988).

In the present study, serum concentrations of prolactin reached maximum levels while concentrations of oestradiol continued to increase in ewes receiving high rates of oestradiol, indicating that prolactin production was maximally stimulated before infusion of oestradiol was stopped. Therefore, secretion of prolactin may be stimulated by increasing concentrations of oestradiol until a maximum level is achieved; then prolactin concentrations decrease regardless of further increases in oestradiol. However, until maximum values of prolactin are reached, increases in oestradiol are needed to stimulate further increases in prolactin. Other investigators have found that increasing concentrations of oestradiol stimulate secretion of prolactin in intact ewes (Baird et al., 1981) and ovariectomized ewes (Elsasser et al., 1983). Conversely, serum concentrations of prolactin did not increase in ewes receiving implants of oestrdiol (Deaver \& Dailey, 1983), further suggesting that concentrations of oestradiol must increase to stimulate secretion of prolactin in ewes.

We thank Dr R. L. Butcher for the oestradiol antiserum; Dr J. J. Reeves for the LH antiserum; Dr L. E. Reichert, Jr, for purified LH for iodination; and NIDDKD for purified preparations of ovine $\mathrm{LH}, \mathrm{FSH}$ and prolactin and antisera to ovine prolactin and $\mathrm{FSH}$. This paper is a contribution from the Missouri Agricultural Experiment Station Journal Series No. 10900.

\section{References}

Adams, T.E., Kinder, J.E., Chakraborty, P.K., Estergreen, V.L. \& Reeves, J.J. (1975) Ewe luteal function influenced by pulsatile administration of synthetic LHRH/FSHRH. Endocrinology 97, 1460-1467.

Baird, D.T., Swanston, I.A. \& McNeilly, A.S. (1981) Relationship between $\mathrm{LH}, \mathrm{FSH}$, and prolactin concentration and the secretion of androgens and estrogens by the preovulatory follicle in the ewe. Biol. Reprod. 24, 1013-1025.

Butcher, R.L., Collins, W.E. \& Fugo, N.W. (1974) Plasma concentration of $\mathrm{LH}, \mathrm{FSH}$, prolactin, progesterone and estradiol-17 $\beta$ throughout the 4-day estrous cycle of the rat. Endocrinology 94, 1704-1708.

Clarke, I.J. \& Cummins, J.T. (1982) The temporal relationship between gonadotropin releasing hormone $(\mathrm{GnRH})$ and luteinizing hormone (LH) secretion in ovariectomized ewes. Endocrinology 111, 1737-1739.

Clarke, I.J., Cummins, J.T., Crowder, M.E. \& Nett, T.M. (1988) Pituitary receptors for gonadotropin-releasing hormone in relation to changes in pituitary and plasma gonadotropins in ovariectomized hypothalamo/pituitary-disconnected ewes. II. A marked rise in receptor number during the acute feedback effects of estradiol. Biol. Reprod. 39, 349-354.

Clarke, I.J., Cummins, J.T., Crowder, M.E. \& Nett, T.M. (1989) Long-term negative feedback effects of oestrogen and progesterone on the pituitary gland of the long-term ovariectomized ewe. J. Endocr. 120, 207-214.

Crowder, M.E., Gilles, P.A., Tamanini, C., Moss, G.E. \& Nett, T.M. (1982) Pituitary content of gonadotropins and GnRH-receptors in pregnant, postpartum and steroid-treated OVX ewes. J, Anim. Sci. 54, 1235-1242.

Deaver, D.R. \& Dailey, R.A. (1983) Effects of dopamine and serotonin on concentrations of luteinizing hormone and estradiol- $17 \beta$ in plasma of cycling ewes. Biol. Reprod. 28, 870-877.

Elsasser, T.H., Bolt, D.J., Bradley, B.D. \& Roper, M. (1983) Luteinizing hormone, follicle stimulating hormone and prolactin secretion in ewes and wethers after zeranol or estradiol injection. J. Anim. Sci. 57, 443-448.

Emons, G., Brack, C., Chatelain, R., Abel, H.H., Isedor, S. \& Ball, P. (1984) Effects of continuous infusions of 4-hydroxyoestradiol and oestradiol on plasma LHlevels in the ovariectomized ewe. Acta endocr. Copenh. 107, 328-336.

Fogwell, R.L., Lewis, G.S., Butcher, R.L. \& Inskeep, E.K. (1977) Effects of ovarian bisection on response to intrafollicular injection of $\mathrm{PGF}_{2} \alpha$ and on follicular development in ewes. J. Anim. Sci. 45, 328-335.

Foster, D.L. (1984) Preovulatory gonadotropin surge system of prepubertal female sheep is exquisitely sensitive to the stimulatory feedback action of estradiol. Endocrinology 115, 1186-1191.

Gill, J.L. \& Hafs, H.D. (1971) Analysis of repeated measurements of animals. J. Anim. Sci. 33, 331-336.

Goding, J.R., Catt, K.J., Brown, J.M., Kaltenbach, C.C., Cumming, I.A. \& Mole, B.J. (1969) Radioimmunoassay for ovine luteining hormone. Secretion of luteinizing hormone during estrus and following estrogen administration in the sheep. Endocrinology 85, 133-142.

Goodman, R.L., Legan, S.J., Ryan, K.D., Foster, D.L. \& Karsch, F.J. (1981) Importance of variations in behavioural and feedback actions of oestradiol to the control of seasonal breeding in the ewe. J. Endocr. 89, 229-240.

Gregg, D.W. \& Nett, T.M. (1989) Direct effects of estradiol-17ß on the number of gonadotropin-releasing 
hormone receptors in the ovine pituitary. Biol. Reprod. 40, 288-293.

Harden, T.K., Cotton, C.U., Waldo, G.L., Lutton, J.K. \& Perkins, J.P. (1980) Catecholamine-induced alteration in sedimentation behavior of membrane bound $\beta$ adrenergic receptors. Science, $N Y 210,441-443$.

Haresign, W. \& Friman, B.R. (1983) Response of ovariectomized ewes to injection of oestradiol- $17 \beta$ at different times of the year. J. Reprod. Fert. 69, 469-472.

Henderson, K.M., Ellen, R.L., Savage, L.C. \& McNatty, K.P. (1989) Studies of the effectiveness of gonadotrophin-releasing hormone, steroids and follicular fluid in modulating ovine gonadotrophin output in vivo and in vitro. J. Reprod. Fert. 86, 105-117.

Hwan, J.C. \& Freeman, M.E. (1987) Partial purification of a hypothalamic factor that inhibits gonadotropinreleasing hormone-stimulated luetinizing hormone release. Endocrinology 120, 483-490.

Karsch, F.J., Legan, S.J., Ryan, K.D. \& Foster, D.L. (1980) Importance of estradiol and progesterone in regulating $\mathrm{LH}$ secretion and estrous behavior during the sheep estrous cycle. Biol. Reprod. 23, 404-413.

Karsch, F.J., Bittman, E.L., Foster, D.L., Goodman, R.L., Legan, S.J. \& Robinson, J.E. (1984) Neuroendocrine basis of seasonal reproduction. Recent Prog. Horm. Res. 40, 185-232.

Keisler, D.H., Inskeep, E.K. \& Dailey, R.A. (1983) First luteal tissue in ewe lambs: influence on subsequent ovarian activity and response to hysterectomy. $J$. Anim. Sci. 57, 150-156.

Keisler, D.H., Inskeep, E.K. \& Dailey, R.A. (1985) Roles of pattern of secretion of luteinizing hormone and the ovary in attainment of puberty in ewe lambs. Dom. Anim. Endocr. 2, 123-132.

Koninckx, P., DeHertogh, R., Heyns, W., Meulepas, E., Brosens, I. \& DeMoor, P. (1976) Secretion rates of LH and FSH during infusion of LH-FSH/RH in normal women and in patients with secondary amenorrhea: suggetive evidence for two pools of $\mathbf{L H}$ and FSH. J. clin. Endocr. metab. 43, 159-167.

Landefeld, T.D. \& Kepa, J. (1984) Pituitary $\alpha$ subunit mRNA amounts during the sheep estrous cycle. $J$. biol. Chem. 259, 12 817-12820.

Leung, K., Kim, K.E., Maurer, R.A. \& Landefeld, T.D. (1988) Divergent changes in the concentrations of gonadotropin $\beta$-subunit messenger ribonucleic acid during the estrous cycle of sheep. Molec. Endocr. 2, 272-276.
Levine, J.E. \& Duffy, M.T. (1988) Simultaneous measurement of luteinizing hormone (LH)-releasing hormone, LH, and follicle-stimulating hormone release in intact and short-term castrate rats. Endocrinology 122, 2211-2221.

Lloyd, J.M. \& Childs, G.V. (1988) Changes in the number of GnRH-receptive cells during the rat estrous cycle: biphasic effects of estradiol. Neuroendocrinology 48, 138-146.

Marshall, J.C., Haisenleder, D.J., Ortolano, G.A., Dalkin, A.C., Paul, S.J. \& Landefeld, T.D. (1989) Regulation of gonadotropin subunit gene expression. In Neural Control of Reproductive Function, pp. 255-271. Eds J. M. Lakoski, J. R. Perez-Polo \& D. K. Rassin. Alan R. Liss Inc., New York.

Moss, G.E., Crowder, M.E. \& Nett, T.M. (1981) GnRHreceptor interaction. VI. Effect of progesterone and estradiol on hypophyseal receptors for $\mathrm{GnRH}$, and serum and hypophyseal concentrations of gonadotropins in ovariectomized ewes. Biol. Reprod. 25, 938-944.

Nett, T.M., Crowder, M.E. \& Wise, M.E. (1984) Role of estradiol in inducing an ovulatory-like surge of luteinizing hormone in sheep. Biol. Reprod. 30, 1208-1215.

Ronnekleiv, O.K., Naylor, B.R., Bond, C.T. \& Adelman, J.P. (1989) Combined immunohistochemistry for gonadotropin-releasing hormone $(\mathrm{GnRH})$ and proGnRH, and in situ hydridization for GnRH messenger ribonucleic acid in rat brain. Molec. Endocr. 3, $363-371$.

SAS Institute, Inc. (1985) SAS User's Guide: Statistics, Version 5 Edition, pp. 433-507. SAS Institute, Cary, NC.

Shupnik, M.A., Gharib, S.D. \& Chin, W.W. (1988) Estrogen suppresses rat gonadotropin gene transcription in vivo. Endocrinology 122, 1842-1846.

Steel, R.G.D. \& Torrie, J.H. (1980) Principles and Procedures of Statistics. A Biometrical Approach. McGraw-Hill Book Co., New York.

Zoeller, R.T. \& Young, W.S. (1988) Changes in cellular levels of messenger ribonucleic acid encoding gonadotropin-releasing hormone in the anterior hypothalamus of female rats during the estrous cycle. Endocrinology 123, 1688-1689.

Received 15 August 1989 